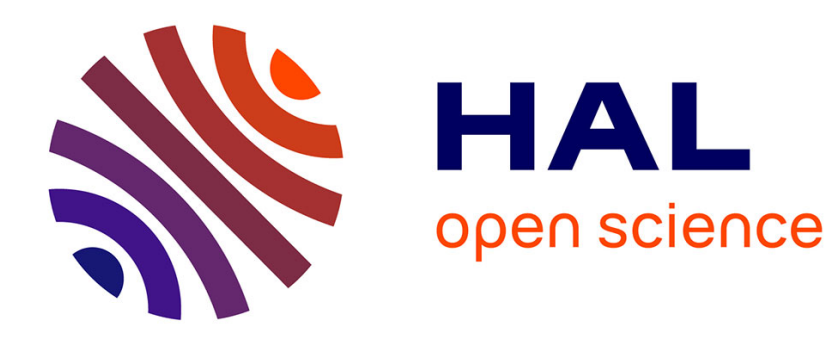

\title{
The role of extreme events in evolution
}

C. Combes

\section{- To cite this version:}

C. Combes. The role of extreme events in evolution. Comptes Rendus Géoscience, 2008, 340, pp.591594. 10.1016/j.crte.2008.01.003 . halsde-00344733

\section{HAL Id: halsde-00344733 \\ https://hal.science/halsde-00344733}

Submitted on 5 Dec 2008

HAL is a multi-disciplinary open access archive for the deposit and dissemination of scientific research documents, whether they are published or not. The documents may come from teaching and research institutions in France or abroad, or from public or private research centers.
L'archive ouverte pluridisciplinaire HAL, est destinée au dépôt et à la diffusion de documents scientifiques de niveau recherche, publiés ou non, émanant des établissements d'enseignement et de recherche français ou étrangers, des laboratoires publics ou privés. 
Comptes Rendus Geoscience (2008) 340 : 591-594

Le rôle des événements extrêmes dans l'évolution

The role of extreme events in evolution

Claude Combes

Université Via Domitia, Avenue Paul Alduy, 66860 Perpignan Cedex (France)

Tel : (33) 468662050 Fax : (33) 0468662152

combes@univ-perp.fr 


\section{Résumé}

Les évolutionnistes ont souvent eu tendance à penser que, au cours des temps, les événements qui se sont produits sur la planète n'avaient jamais été très différents de ceux que l'on observe au cours d'une vie humaine. Cependant, lorsqu'une échelle de temps « non humaine » est utilisée, l'histoire du globe apparaît profondément et fréquemment bouleversée par des événements extrêmes. Ceux-ci, même s’ils ne sont pas toujours instantanés dans le sens courant du mot, sont, à cause de leur amplitude, responsables d'une sélection sévère, non entre les individus d'une espèce mais entre les espèces, ou même entre des clades. Dans la confrontation avec un événement extrême, la diversité intraspécifique compte peu, c’est la diversité interspécifique qui fait la différence.

Ainsi que le montrent les extinctions en masse, les événements extrêmes ouvrent des espaces et redistribuent les cartes du monde vivant, offrant aux survivants des opportunités de radiation. La capacité de survivre à des conditions de milieu se modifiant brusquement favorise certaines espèces dans les écosystèmes, bien plus que certains individus dans les populations. Pour autant, il ne s'agit pas là d'un processus macroévolutif qui se caractériserait par l'apparition soudaine de nouvelles adaptations, mais d'un processus macroévolutif en ce sens qu'il élague des pans entiers de la biosphère. Le plus important est peut-être que la "médiatisation » actuelle de quelques grandes extinctions en masse dissimule des extinctions moins grandioses causées par des événements extrêmes un peu moins extrêmes et plus localisés qui, tout au long de l'évolution, ont pu être responsables de nombreux changements de composition et de structure des communautés. Le terme de «pré-adaptation » a été progressivement abandonné parce qu'il peut donner l'impression d'un certain finalisme. Lorsqu'il est question des événements extrêmes, il exprime bien le fait que, lorsqu'un événement non prévisible survient, une espèce donnée possède ou non les «bons gènes » pour maintenir des populations viables. Le rôle des événements extrêmes dans l'évolution de la vie ne devrait donc jamais être sous-estimé. 


\section{Abstract}

Evolutionnists have often had a marked tendency to think that, in the course of times, planetary events were not very different from those occuring during a human life. However, when a " not human » time scale is used, the history of our planet appears to be profoundly and frequently disturbed by extreme events. These events, even not always instantaneous, impose - because of their amplitude - a severe sorting, not between individuals of a species, but between species, or even between phyla. In the face of an extreme event, intraspecific diversity counts little, it is the interspecific diversity which makes the difference.

As shown by mass extinctions, extreme events open ecological niches and redistribute the cards of life, giving survivors opportunities to radiate. The capacity to cope with extreme ecological conditions favors certain species in ecosystems, not certain individuals in populations. This is not a macroevolutionary process in terms of acquiring new adaptations, but a macroevolutionary process in terms of sorting entire sections of life. The most important is perhaps that the current " mediatization » of a limited number of mass extinctions dissimulates less important extinctions caused by less extreme and more localized events that were possibly responsible for many changes in the composition and structure of communities throughout the evolution.

The term of «pre-adaptation » has been neglected because it gives an impression of finalism, but it expresses well that, when an unexpected event occurs, a particular species has or has not the « right genes » to continue to sustain viable populations. The role of extreme events in modifying the course of evolution should not be underestimated. 
When we talk about ecosystems, there are two units of life which are always taken into account, the individual and the species. A paradox is that, whereas birth and death of individuals do not raise (in general) any problem, birth and death of species are far from the same status : in spite of many efforts, those of Stephen Jay Gould for instance, we know little about the "demography » of species, particularly the processes which govern their extinction. As a matter of fact, we do not fully understand the reasons why both individuals and species die...

Cuvier, in his "Discours sur les révolutions du globe » assigned catastrophes a pivotal role in the history of life. Cuvier supposed that there had been sudden natural catastrophes such as floods or formation of high mountains. Organisms were locally killed off and new species moved from different areas. On the contrary, Charles Lyell opposed the concept of uniformitarism (see [1]) to Cuvier's catastrophism and Charles Darwin himself attributed limited importance, if any, to natural catastrophes. For a long time, evolutionists did the same.

Darwin considered that natural selection operates essentially at the level of individuals. In contrast, Stephen Jay Gould (and other evolutionists, like Sewall Wright, long before) drew attention to the fact that selection may act at different levels: "The death of some groups in mass extinctions and the survival of others, while surely not random, probably bears little relationship to the evolved, adaptive reasons for success of lineages in normal Darwinian times dominated by competition [...] Immediate adaptation may bear no relationship to success over immensely long periods of geological change. » [2]

Gould put a special emphasis on species selection, with his famous metaphore of two fish species in a lake: one species is perfectly adapted to well-aerated waters, the second is less specifically adapted but is able to survive in various areas of the lake. When the quality of water is modified by a climatic change or another event, for instance when the lake is replaced by a pond with poorly aerated water, only 
the " poorly adapted » species survives. In this imaginary example of species selection, Gould considers that is its higher genetic diversity which gives the second species a selective advantage when the event occurs. Clearly, the drying of the lake is an extreme event, despite its small scale.

Defining what an extreme event is exactly, is difficult, but is particularly relevant when the role of extreme events in the evolutionary process is being considered. An " organism based» definition is for instance the one proposed by Gutschick \& BassiriRad: "An extreme event is an episode in which the acclimatory capacities of an organism are substantially exceeded » [3]. Only, one may replace « organism » by « species »

Clearly, different types of extreme events will not produce the same pressures on life. I am using the word " pressures » because the simple hypothesis that extreme events play a role in evolution implies that they exert pressures in the same way "not extreme events » do. Of course, the expression " in the same way » does not mean " with the same consequences ». Whereas "not extreme events » intervene in modifying the frequency of genes in populations, extreme events modify biodiversity at a higher level, i. e. ecosystems. By doing that, extreme events disrupt selective pressures in these ecosystems.

A question is : if an extreme event provokes the extinction of certain species, while preserving others, can we speak of species selection? The concept of species selection has been criticized with the principal argument that any adaptation characterizing a species arose in the first place by interactions between individuals of that species, "not because of interactions among species as discrete and bounded units » [4]. This is certainly true and valid as long as selection is a slow, routine process, giving individuals different probabilities of transmitting their genes to the next generation.

Vincent Courtillot [5] insists on the fact that evolutionnists have often had a marked tendency to think that, in the course of times, planetary events were not very different from those occuring during a human life. It is possible that the souvenir of "Cuvier's catastrophism » made people reluctant to accept a "new catastrophism ». However, when a «not human » time scale is used, 
the history of our planet appears to be profoundly and frequently disturbed by extreme events, principally climatic. These events, even not always instantaneous, impose - because of their amplitude - a severe sorting, not between individuals of a species, but between species, or even between phyla. In the face of an extreme event, intraspecific diversity counts little, it is the interspecific diversity which makes the difference.

As shown by mass extinctions, extreme events modify profoundly the structure of ecosystems, open spaces in which new ecological niches can emerge, and redistribute the cards of life, giving survivors opportunities to radiate : at least to a certain extent, «the greater the scope and intensity of an extinction event, the greater the scope and intensity of evolutionary response » [6]. The capacity to cope with extreme ecological conditions favors certain species in ecosystems, not certain individuals in populations. This is not a macroevolutionary process in terms of acquiring new adaptations, but a macroevolutionary process in terms of sorting entire sections of life. The "énorme loterie " evoked by J. Monod [7] distributes prizes of variable values... The most important is perhaps that the current emphasis on a limited number of mass extinctions dissimulates less important extinctions caused by less extreme and more localized events that were possibly responsible for many changes in the composition and structure of communities throughout the evolution.

Quite a lot of evolutionnist names come to mind when " uniformitarism » is questionned. Among them, however, Gould adds something that Eldrege summarized in the following words at the memorial service for Gould at New-York University : "Steve used the term contingency to refer to the pattern where some entire groups will succomb to extinction where others may squeak through all, as far as can be told, having nothing to do with how well adapted they were to their normal environments »

Although I am very often in agreement with Gould's views, this is a point I do not follow. It concerns contingency. Extreme events have a selective role. I agree that the kind of selection they are responsible of has nothing to do with " how well adapted organisms were to their normal environments ", but they have something to do with, for instance, their size, their foraging habits, their diet, their generation 
time, the fact that they live in the soil or in the trees, in shallow or profound water, their dispersal ability, resistance to pathogens, etc. The term of pre-adaptation proposed long ago by L. Cuénot has been more or less neglected because it gives an impression of finalism, but it is probably the best one to express that, when an unexpected and sudden event occurs, a particular species has or has not the « right genes » to continue to sustain viable populations.

In the course of time, biodiversity is submitted repeteadly to at least two « natural » selective processes : 1) natural selection of individual phenotypes in the darwinian sense of the terms ; 2) natural (I insist on « natural ») selection of species, each time there is an extreme event. In other words, genetic informations are submitted to sorting in two successive different packages, first as genomes, secund as gene pools. Gene pool can characterize a group, a population, a species, a phylum. It is in the case of species and phyla that the impact on evolution is the higher. These two processes, one humdrum, the other spectacular, can be compared to the continuous control and the sudden examinations that certain university teachers sometimes impose their students. The Red Queen is usually described as a process which provokes the acquisistion of a chain of successive adaptations. Extreme climatic events may strongly modify the fitness of the competing species and make a Red Queen process stop.

It must be added that extreme events must be seen sometimes as cascades of events. For instance, a strong volcanic eruption will cause an extreme climatic event which will cause an extreme epidemiologic event, and so on. A genetic combination of viruses, an acquisition of plasmides by a bacteria strain, a host switching for a parasite are extreme events that can have important evolutionary consequences. Certain extreme events may even increase (or reduce) the rate of mutations, due to temperature change or radioactive substances.

I thus conclude that the role of extreme climatic events in modifying the course of evolution should never be underestimated. Although some extreme events could provoke the end of our species nowadays, one may speculate that, without many of them, we would simply be absent. 


\section{References}

[1] Virgili C., Charles Lyell and scientific thinking in geology. C.R. Géosciences, 339, 8 (2007) : 572-584.

[2] Gould S. J., Darwinian Fundamentalism. The New-York Review of Books, June 12, 1997.

[3] Gutschick V. P. \& BassiriRad H., Extreme events as shaping physiology, ecology, and evolution of plants: toward a unified definition and evaluation of their consequences. New Phytologist 160 (2003) : 21-42.

[4] Zimmerman W. F., Stephen Jay Gould's Final View of Evolution. The Quarterly Review of Biology 78 (2003): 454-459.

[5] Courtillot V. : La dynamique du globe contrôle-t-elle l'évolution des espèces ?, in : Michaud Y. (Ed.): "Qu'est-ce que la vie?" Université de tous les savoirs. Odile Jacob, Paris, 2000.

[6] Eldredge, N., Homage to Steve Gould. Paleobiology 28 (2002) : 301-303.

[7] Monod J. : Le hasard et la nécessité. Seuil, Paris, 1970. 